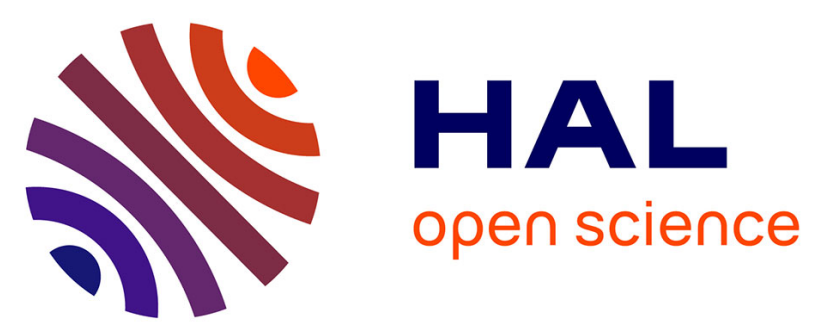

\title{
Automated classification of early afterdepolarizations grades in flipr calcium assays
}

Levy Batista, Ricardo Contu, Brittney van Hese, Fabian Zanella, Thierry

Bastogne

\section{- To cite this version:}

Levy Batista, Ricardo Contu, Brittney van Hese, Fabian Zanella, Thierry Bastogne. Automated classification of early afterdepolarizations grades in flipr calcium assays. Annual Meeting of Safety Pharmacology Society, SPS 2018, Sep 2018, Washington DC, United States. hal-01925678

\section{HAL Id: hal-01925678 \\ https://hal.science/hal-01925678}

Submitted on 17 Nov 2018

HAL is a multi-disciplinary open access archive for the deposit and dissemination of scientific research documents, whether they are published or not. The documents may come from teaching and research institutions in France or abroad, or from public or private research centers.
L'archive ouverte pluridisciplinaire HAL, est destinée au dépôt et à la diffusion de documents scientifiques de niveau recherche, publiés ou non, émanant des établissements d'enseignement et de recherche français ou étrangers, des laboratoires publics ou privés. 


\section{AUTOMATED CLASSIFICATION OF EARLY AFTERDEPOLARIZATIONS GRADES IN FLIPR CALCIUM ASSAYS \\ L. BATISTA ${ }^{1}$, R. CONTU2 2 , B. VAN HESE ${ }^{2}$, F. ZANELLA ${ }^{2}$, T. BASTOGNE1, 1,4 \\ 'CYBERnano, 2STEMONIX, ${ }^{3}$ CRAN UL-CNRS UMR 7039, 4 INRIA BIGS}

\section{Objectives}

The detection and classification of proarrhythmic phenotypes like early afterdepolarizations (EADs) is fundamental in the safety pharmacology assessment of developing drugs. Calcium flux analysis enables sensitive and high throughput in vitro assays to assess potential cardiac liabilities of compounds of interest in cardiomyocytes, generating large amounts of multi-parametric data in a single experiment. However, instrument-agnostic, robust automated data analysis platforms to predict and characterize EADs are not readily available.

\section{Methods}

We developed a new integrated approach able to automatically classify severity grades of EADs observed in high throughput calcium flux data. Stemonix microHeart screening plates promote cardiomyocyte alignment and enable greater resolution over the analysis of pro-arrhythmic phenotypes observed in human induced pluripotent stem cell-derived cardiomyocytes (hiPSC-CMs). hiPSC-CMs were maintained in standard or microengineered microHeart 384-well screening plates for seven days prior to compound treatment and calcium flux analysis. Compound responses were categorized into 7 phenotypes: normal rythmic calcium flux behavior, five severity grades of EADs, and cessation of beating activity (quiescence). Data generated in the microHeart platform was used by Cybernano to develop and validate a statistical learning algorithm: Cybernano i-Cardio EAD to characterize transient patterns associated with different classes of EADs. Parametric modeling of the beating pattern was associated with a numeric degree of EADs with a value normalized between 0 (no beating) and 1 (no EAD). Finally, an multiclass classification is applied to discriminate the five severity grades of EADs.

\section{Results}

EAD classifications obtained from standard manual data plotting were compared to classifications obtained with Cybernano algorithms, and concordance between the datasets was analyzed for validation. Robust concordance was observed through this analysis, indicating that the algorithm has satisfactory fidelity to streamline data analysis for automated detection of EADs from high throughput calcium flux analysis in cardiomyocytes.

\section{Conclusion}

In summary, the comparison of data analysis obtained have demonstrated the proof of concept and very promising perspectives for automatic detection and grading EADs in high throughput calcium flux assays. This comparative study will serve as basis for extending the analysis to a larger library of molecules for additional validation.

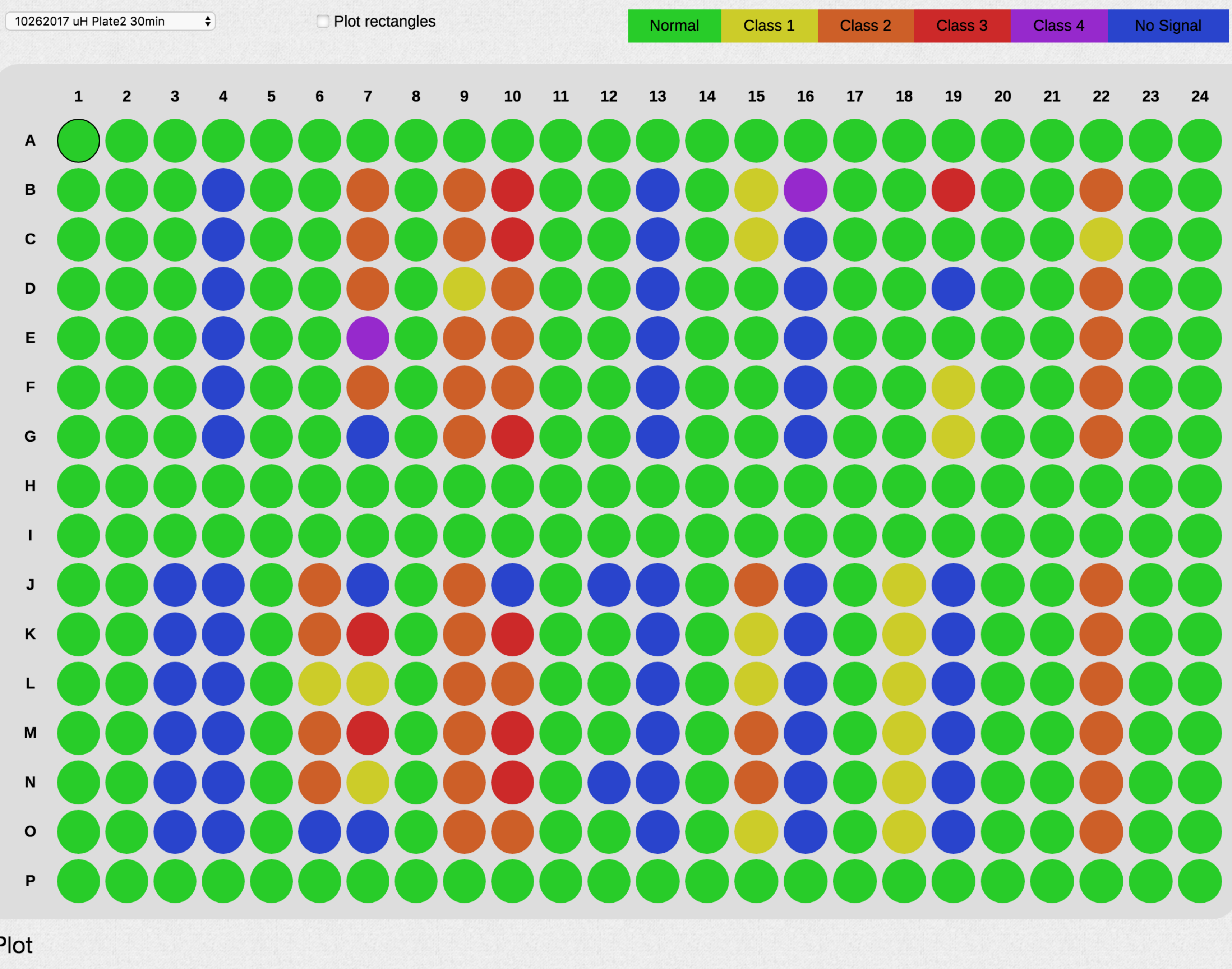
Plot
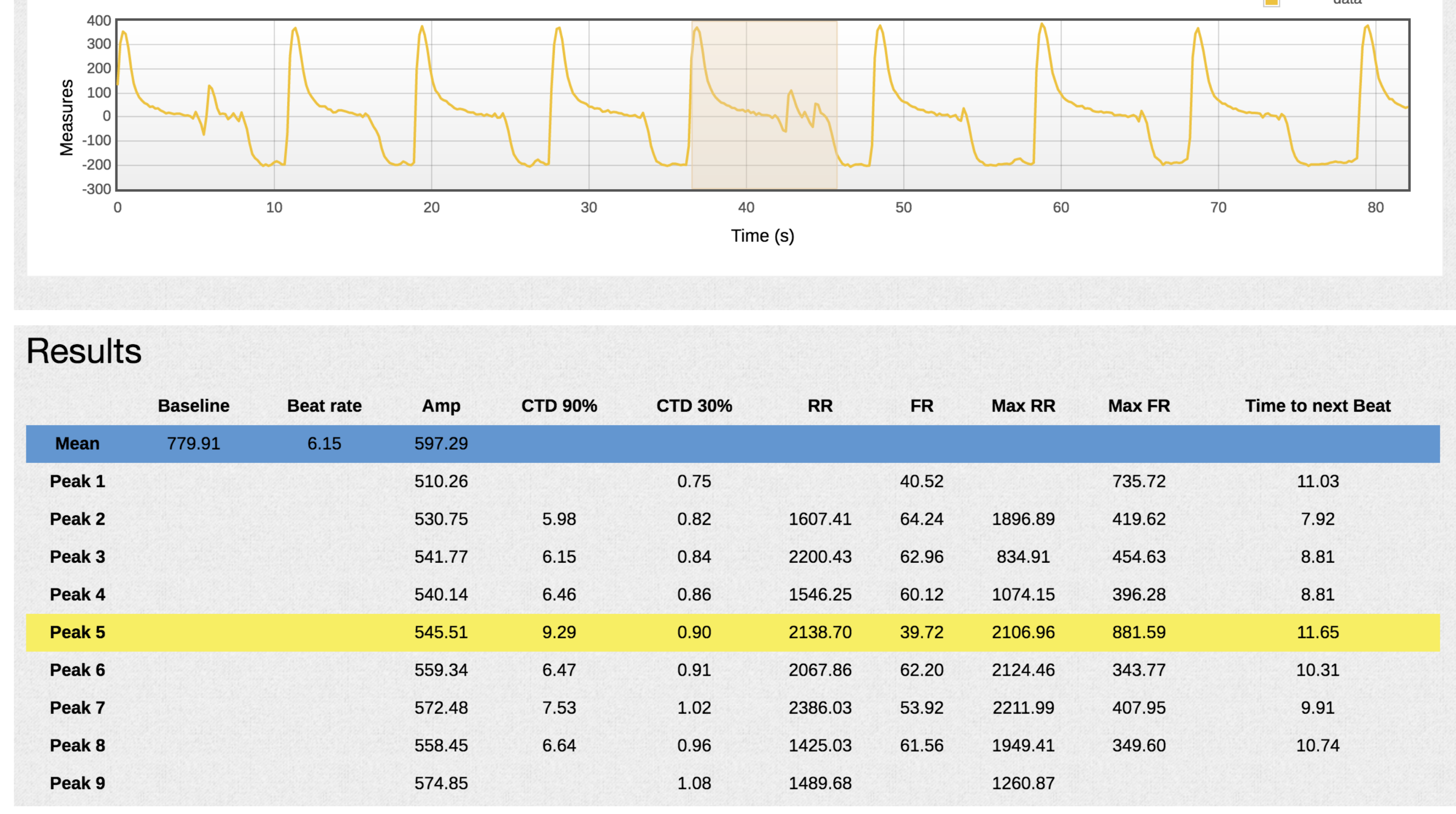

Fig. 1: Example of i-Cardio EAD report obtained from FLIPR data of a 384well screening plate. Each colour corresponds to a EAD severity grade on a scale composed of 5 levels.

\begin{tabular}{|l|l|r|r|r|r|r|r|r|r|}
\hline & \multicolumn{10}{|c|}{ PREDICTED } \\
\hline & Nomal & EAD-1 & EAD-2 & EAD-3 & EAD-4 & No Signal & Undefined \\
\hline Nomal & 1265 & 3 & 0 & 0 & 0 & 3 & 0 \\
\hline EAD-1 & 1 & 34 & 6 & 1 & 0 & 0 & 0 \\
\hline EAD-2 & 0 & 7 & 49 & 2 & 0 & 0 & 0 \\
\hline EAD-3 & 0 & 0 & 13 & 18 & 0 & 1 & 4 \\
\hline EAD-4 & 0 & 0 & 0 & 4 & 4 & 1 & 0 \\
\hline No Signal & 0 & 0 & 0 & 0 & 0 & 81 & 0 \\
\hline Undefined & 0 & 0 & 0 & 6 & 0 & 17 & 16 \\
\hline
\end{tabular}

Fig.2: Confusion matrix presenting the performances of the automatic $E A D$ classification

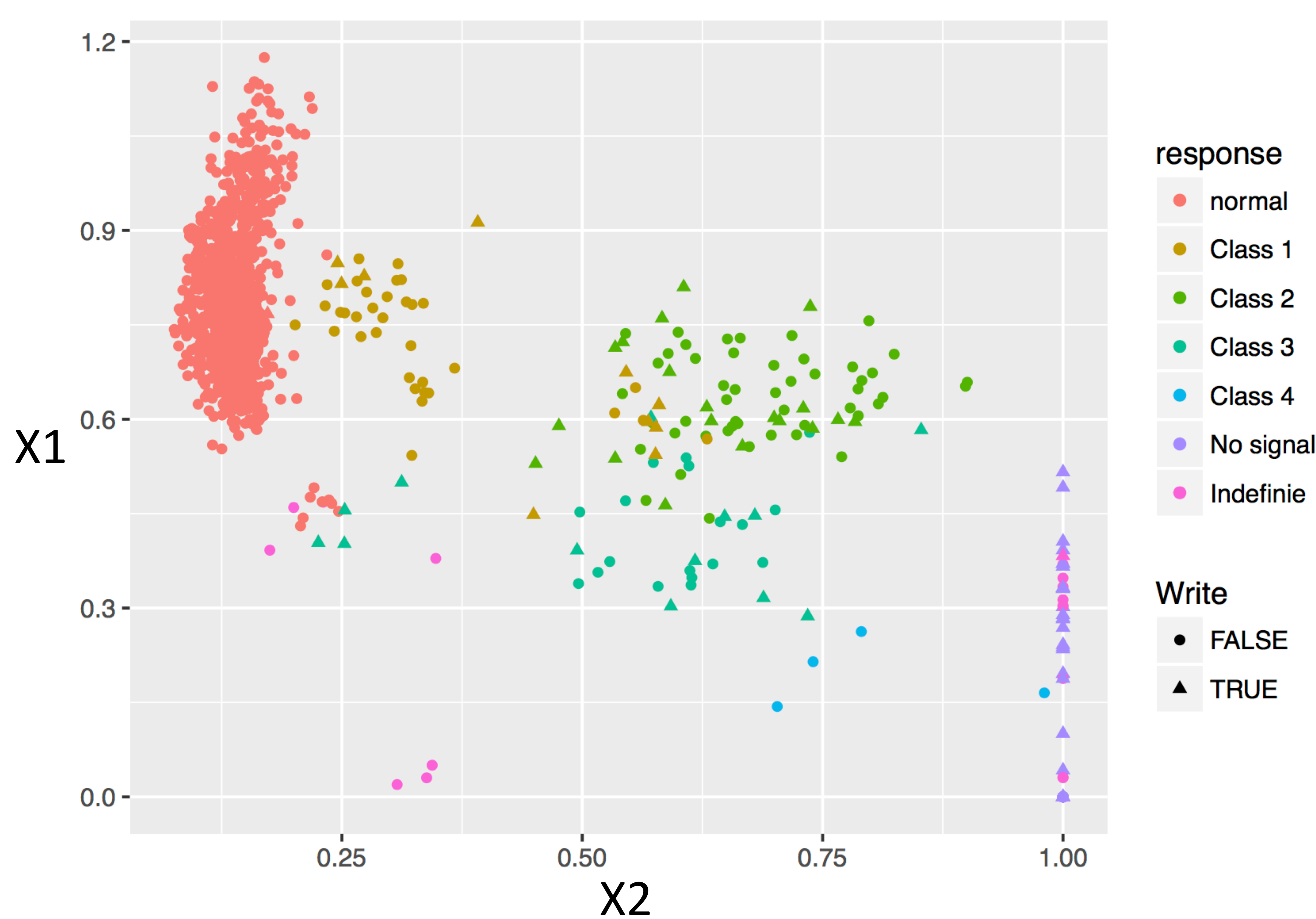

Fig.3: Visualization of the EAD classes in a 2D-space associated with 2 classifiers: $X 1$ and $X 2$. 